\title{
HUBUNGAN SIKAP IBU YANG MEMPUNYAI BAYI DENGAN PELAKSANAAN IMUNISASI DPT DI PUSKESMAS KAWALI KABUPATEN CIAMIS TAHUN 2018
}

\author{
Dini Nurbaeti Zen ${ }^{1 *}$, Tita Rohita ${ }^{1}$, Siti Sopiah ${ }^{1}$ \\ ${ }^{1}$ Program Studi Keperawatan Fakultas Ilmu Kesehatan Universitas Galuh Ciamis \\ Korespondensi e-mail: rohitatita@gmail.com
}

(Diterima 22 Oktober 2018; disetujui 15 -12-2018; dipublish 31-1-2019)

\begin{abstract}
ABSTRAK
Berdasarkan Survey Penduduk Antar Sensus (SUPAS) 2015 menunjukan AKB sebesar 22,23 per 1.000 kelahiran hidup. Sedangkan AKABA sekitar 26,29 per 1.000 kelahiran hidup.Diperkirakan1,7 juta kematian atau 5\% terjadi pada balita di Indonesia adalah akibat PD3I. Kasus PD3I yang sangat menjadi perhatian yang besar akhir-akhir ini adalah dilaporkan beberapa daerah di Indonesia dinyatakan telah terjadi Kejadian Luar Biasa (KLB) difteri. Angka kematian akibat difteri di Indonesia sekitar 15\% dan terus mengalami peningkatan (Vivi Triania, 2015). Suatu sikap belum otomatis terwujud dalam suatu tindakan (overt behavior). Untuk mewujudkan sikap menjadi suatu perbuatan nyata diperlukan faktor pendukung atau suatu kondisi yang memungkinkan, antara lain adalah fasilitas.Komponen sikap terdiri dari tiga, yaitu kognitif, afektif dan konatif, dimana ketiga kompenen ini bersama-sama membentuk sikap yang utuh (total attitude). Dalam penentuan sikap yang utuh ini, pengetahuan, berpikir, keyakinan dan emosi memegang peranan penting. Tujuan dari penelitian ini adalah untuk mengetahui hubungan sikap ibu yang mempunyai bayi dengan pelaksanaan imunisasi DPT di puskesmas Kawali. Metode penelitian yang digunakan adalah analisa univariat dan bivariat. Hasil penelitian di wilayah kerja Puskesmas Kawali mengenai adanya hubungan antara sikap ibu yang mempunyai bayi dengan pelaksanaan imunisasi DPT didapat kesimpulan hasil uji Chi Squares, didapatkan nilai $\rho=0,00$ atau $\rho<\alpha=0,05$ berarti ada hubungan antara sikap ibu dengan pelaksanaan imunisasi DPT tahun 2018. Disarankan hasil penelitian bisa dijadikan bahan referensi dalam penelitian selanjutnya.
\end{abstract}

Kata kunci : Sikap dan pelaksanaan imunisasi DPT.

Daftar Pustaka : 37 (2007-2017)

\section{PENDAHULUAN}

Imunisasi DPT adalah vaksinasi

yang diberikan untuk menimbulkan

kekebalan aktif dalam waktu yang

bersamaan terhadap penyakit difteri,

pertusis (batuk rejan/ batuk seratus hari),

dan tetanus. DPT merupakan vaksin yang

mengandung racun kuman difteri yang

telah dihilangkan sifat racunnya, namun

masih dapat merangsang pembentukan zat

anti (toksoid) (Puri Mahayu, 2016).

Imunisasi telah diakui sebagai upaya

pencegahan penyakit yang paling tepat

dan berdampak terhadap peningkatan

kesehatan masyarakat serta dapat menurunkan angka kejadian penyakit yang dapat dicegah dengan imunisasi. Menurut Departemen Kesehatan Republik Indonesia 2013, Peningkatan derajat kesehatan anak ini dapat dicapai dengan pelaksanaan imunisasi selain dari perbaikan status sosial dan ekonomi masyarakat.

Dari data Kementrian Kesehatan Republik Indonesia tercatat, hingga akhir November 2017, terdapat 95 kabupaten/kota di 20 provinsi yang melaporkan kasus difteri. Per 16 Desember 2017 kasus difteri sudah ditemukan di 26 provinsi. Kasus terbanyak ditemukan di Jawa Timur yang disusul Jawa Barat. Dengan banyak nya kasus 
difteri di Indonesia, maka terdapat kebijakan pemberian imunisasi tambahan difteri di wilayah tersebut atau Outbreak Response Immunization (ORI). Ini adalah pemberian khusus pada populasi yang beresiko tertular penyakit difteri (Kemenkes RI,2017).Berdasarkan laporantahunan Dinas Kesehatan Kabupaten Ciamis tahun 2017, terdapat 6 kasus kejadian difteri dan ada 2 pasien meninggal akibat difteri. (DinkesCiamis, 2017).

Dampak positif imunisasi DPT bagi kesehatan bayidiantaranya adalah untuk menurunkan angka kesakitan dan kematian akibat penyakit difteri, pertusis, tetanusdan dapat mencegah penyebaran penyakit lebih lanjut.Agar halinibisatercapai, bayi 0-11 bulandiwajibkanimunisasi DPT. (Depkes RI, 2013).

Hasil Survei Penduduk Antar Sensus (SUPAS) 2015 menunjukan AKB sebesar 22,23 per 1.000 kelahiran hidup, yang artinya sudah mencapai target MDG 2015 sebesar 23 per 1.000 kelahiran hidup. Begitu pula dengan Angka Kematian Balita (AKABA) hasil SUPAS 2015 sebesar 26,29 per 1.000 kelahiran hidup, juga sudah memenuhi target MDG 2015 sebesar 32 per 1.000 kelahiran hidup (Depkes RI, 2015).

Diperkirakan1,7 juta kematian atau $5 \%$ terjadi pada balita di Indonesia adalah akibat PD3I. Kasus PD3I yang sangat menjadi perhatian yang besar akhir-akhir ini adalah dilaporkan beberapa daerah di Indonesia dinyatakan telah terjadi
Kejadian Luar Biasa (KLB) difteri. Angka kematian akibat difteri di Indonesia sekitar $15 \%$ dan terus mengalami peningkatan (Triania, vivi 2015).

Berdasarkan hasil laporan Kementrian Kesehatan jumlah bayi yang mendapatkan imunisasi DPT di Jawa Barat sebanyak 1.692.081 bayi (Kemenkes RI, 2016). Berdasarkan laporan tahunan Dinas Kesehatan Kabupaten Ciamis tahun 2017, cakupan DPT (1) sebanyak 16.716, sedangkan jumlah sasaran 16.974, ada 258 sasaran yang tidak diimunisasi. Cakupan DPT (2) sebanyak 16.475, sedangkan jumlah sasaran 16.974, ada 499 sasaran yang tidak diimunisasi. Cakupan DPT (3) sebanyak 17.246, sedangkan jumlah sasaran 16.974, sasaran diimunisasi semua, bahkan ada 272 yang melebihi dari sasaran (Dinkes Ciamis, 2017).

Puskesmas Kawali merupakan puskesmas yang data cakupan imunisasi DPT nya masih kurang yaitu jumlah DPT(1) sebanyak 236 bayi, sedangkan jumlah sasaran 275 bayi, ada 39 bayi sasaran yang tidak diimunisasi. DPT(2) sebanyak 233 bayi, sedangkan jumlah sasaran 275 bayi, ada 42 bayi sasaran yang tidak diimunisasi. DPT(3) sebanyak 217 bayi, sedangkan jumlah sasaran 275 bayi, ada 58 bayi sasaran yang tidak diimunisasi.

Kendala utama untuk keberhasilan imunisasi bayi dan anak dalam sistem perawatan kesehatan adalah rendahnya kesadaran yang berhubungan dengan tingkat pengetahuan dan tidak adanya kebutuhan masyarakat pada imunisasi, 
jalan masuk ke pelayanan imunisasi tidak adekuat, melalaikan peluang untuk pemberian vaksin dan sumber-sumber yang adekuat untuk kesehatan masyarakat dan program pencegahannya (Notoatmodjo, 2010).

Sikap ibu terhadap imunisasi akan membentuk perilaku yang mendukung terhadap kegiatan imunisasi. Hal ini merupakan faktor dominan dalam keberhasilan imunisasi, dengan sikap yang positif maka diharapkan pelaksanaan imunisasi akan meningkat. Sikap yang dimiliki ibu tersebut akan menimbulkan kepercayaan ibu tentang kesehatan dan mempengaruhi status imunisasi bayi dan balita (Notoatmodjo, 2010).

Suatu sikap belum otomatis terwujud dalam suatu tindakan (overt behavior). Untuk mewujudkan sikap menjadi suatu perbuatan nyata diperlukan faktor pendukung atau suatu kondisi yang memungkinkan, antara lain adalah fasilitas. Sikap ibu yang sudah positif terhadap imunisasi tersebut harus mendapat konfirmasi dari suaminya, dan ada fasilitas imunisasi yang mudah dicapai, agar ibu tersebut mengimunisasikan anaknya. Disamping faktor fasilitas juga diperlukan faktor dukungan (support) dari pihak lain, misal suami atau isterinya, orang tua sangat penting untuk mendukung praktek atau suatu tindakan. Komponen sikap terdiri dari tiga, yaitu kognitif, afektif dan konatif, dimana ketiga kompenen ini bersama-sama membentuk sikap yang utuh (total attitude). Dalam penentuan sikap yang utuh ini, pengetahuan, berpikir, keyakinan dan emosi memegang peranan penting (Notoatmodjo, 2010).

Dari survey pendahuluan yang dilaksanakan di wilayah kerja puskesmas Kawali dengan wawancara terhadap 10 ibu bayi yang masih belum diimunisasi DPT, didapatkan bahwa 2 ibu bayi mengatakan anaknya tidak diimunisasi karena takut anaknya jatuh sakit atau panas seperti imunisasi sebelumnya, $2 \mathrm{ibu}$ bayi menganggap imunisasi tabu, 3 orang ibu bayi mengatakan anaknya tidak akan diimunisasi karena tempat pelayanan imunisasi DPT jauh, 2 ibu bayi mengatakan tidak akan membawa anaknya ke posyandu atau puskesmas untuk imunisasi DPT karena tidak ada manfaat imunisasi DPT, 1 ibu bayi mengatakan saat kunjungan imunisasi DPT ibu merasa terganggu karena akan membawa bayi ke posyandu atau puskesmas.

Dari fenomena tersebut diatas, maka penulis merasa tertarik untuk melakukan penelitian tentang "Hubungan Sikap Ibu Yang Mempunyai Bayi Dengan Pelaksanaan Imunisasi DPT di Puskesmas Kawali Kabupaten Ciamis Tahun 2018”. Berdasarkan latar belakang diatas, maka rumusan masalah dalam penelitian ini adalah, "Adakah Hubungan Antara Sikap Ibu Yang Mempunyai Bayi Dengan Pelaksanaan Imunisasi DPT di Wilayah Puskesmas Kawali Kabupaten Ciamis Tahun 2018?" 


\section{METODE PENELITIAN}

Tujuan dalam penelitian adalah untuk mengetahui hubungan sikap ibu yang mempunyai bayi dengan pelaksanaan imunisasi DPT di Puskesmas Kawali Kabupaten Ciamis Tahun 2018.

Penelitian ini merupakan jenis penelitian kolerasional, yaitu mencari hubungan antara variabel independen dengan variabel dependen, desain penelitian yang digunakan dengan cara cross sectional yaitu suatu penelitian dimana variabel yang termasuk faktor resiko dan variabelvariabel yang termasuk efek diobservasi sekaligus pada waktu yang sama (Notoatmodjo 2010, dalam sulaeman 2012).

Populasi dalam penelitian ini adalah ibu yang mempunyai bayi di Puskesmas Kawali Kabupaten Ciamis sebanyak 275 orang. Pengambilan sampel dengan teknik proporsional random sampling yaitu pengambilan sampel secara acak dan proporsional berdasarkan jumlah populasi dari masing-masing desa. Juml;ah sampel

penelitian se- banyak 73 orang yang dihiung dengan rumus:

$$
n=\frac{N}{N(d)^{2}+1}
$$

Pengumpulan data dilakukan dengan cara wawancara menggunakan kuesioner dan observasi/ telaah dokumen buku KIA, data dianalisis secara univaiat dan bivariat. Analisi univariat dalam bentuk mean atau nilai rata-rata. Sedangkan untuk membuktikan adanya hubungan antara dua variable dilakukan analisa bivariat dengan menggunakan uji statistik Chi Square.

\section{HASIL DAN DISKUSI}

Analisis Univariat

a. Gambaran sikap Ibu dalam pelaksanaan Imunisasi DPT di Puskesmas Kecamatan Kawali tahun 2018

Berdasarkan hasil penelitian maka didapatkan data gambaran sikap Ibu dalam pelaksaan Imunisasi DPT di Puskesmas Kawali tahun 2018 adalah sebagaimana gambarkan pada tabel 1 sebagai berikut:

\section{Tabel 1}

Distribusi Frekuensi sikap Ibu dalam pelaksanaan Imunisasi DPT di Puskesmas Kawali tahun 2018

\begin{tabular}{l|l|c|c} 
No & Kategori & Frekuensi & Persentase (\%) \\
\hline 1 & Positif & 62 & 84.9 \\
\hline 2 & Negatif & 11 & 15.1 \\
\hline Jumlah & & 73 & $100 \%$ \\
\hline
\end{tabular}

Dari tabel 1 diatas dapat dijelaskan bahwa hampir seluruhnya dari jumlah responden yang diteliti memiliki sikap positif terhadap pelaksanaan imunisasi DPT yaitu sebanyak 62 orang $(84,9 \%)$, dan sebagian kecil dari responden yang diteliti memiliki sikap negatifterhadap imunisasi DPT yaitu sebanyak 11 orang $(15,1 \%)$. 
b. Gambaran pelaksanaan Imunisasi DPT pada bayi di Puskesmas Kecamatan Kawali tahun 2018

Berdasarkan hasil penelitian maka didapatkan data gambaran pelaksanaan Imunisasi DPT di

Puskesmas Kawali tahun 2018

sebagaimana gambarkan pada tabel 2 sebagai berikut:

Tabel 2

Distribusi Frekuensi pelaksanaan Imunisasi DPT di Puskesmas Kawali tahun 2018

\begin{tabular}{llcc}
\hline No & Kategori & Frekuensi & Persentase (\%) \\
\hline 1 & Melakukan & 54 & 74.0 \\
\hline 2 & Tidak melakukan & 19 & 26.0 \\
\hline Jumlah & $\mathbf{7 3}$ & $\mathbf{1 0 0} \%$ \\
\hline
\end{tabular}

Dari tabel 2 diatas dapat dijelaskan bahwa hampir seluruhnya dari jumlah responden yang diteliti melakukan Imunisasi DPT yaitu sebanyak 54 orang $(74 \%)$, dan hanya sebagian kecil dari responden yang diteliti tidak melakukan Imunisasi DPT yaitu sebanyak 19 orang $(26 \%)$.

\section{Analisis Bivariat}

Analis bivariat dalam penelitian ini adalah hubungan sikap Ibu dengan pelaksanaan Imunisasi DPT di Puskesmas Kawali tahun 2018, hasil penghitungan data dapat dilihat dalam tabel 3 sebagai berikut :

Tabel 4.3

Hubungan sikap Ibu dengan pelaksanaan Imunisasi DPT di Puskesmas Kawali tahun 2018

\begin{tabular}{|c|c|c|c|c|c|c|c|c|c|}
\hline \multirow{3}{*}{ No } & \multirow{3}{*}{ Sikap Ibu } & \multicolumn{4}{|c|}{$\begin{array}{c}\text { Pelaksanaan Imunisasi } \\
\text { DPT }\end{array}$} & \multirow{2}{*}{\multicolumn{2}{|c|}{ Total }} & \multirow{2}{*}{$\begin{array}{c}\rho \\
\text { value }\end{array}$} & \multirow{2}{*}{$\alpha$} \\
\hline & & \multicolumn{2}{|c|}{ Melakukan } & \multicolumn{2}{|c|}{$\begin{array}{c}\text { Tidak } \\
\text { melakukan }\end{array}$} & & & & \\
\hline & & $\mathbf{F}$ & $\%$ & $\mathbf{F}$ & $\%$ & $\mathbf{F}$ & $\%$ & 0.00 & 0.05 \\
\hline 1 & Positif & 52 & 71,3 & 10 & 13,7 & 62 & 85 & & \\
\hline 2 & Negatif & 2 & 2,7 & 9 & 12,3 & 11 & 15 & & \\
\hline \multicolumn{2}{|c|}{ Jumlah } & 54 & 74 & 11 & 26 & 73 & 100 & & \\
\hline
\end{tabular}

Berdasarkan tabel 3 diatas, dapat diketahui bahwa Ibu yang memiliki sikap positif sebagian besar melakukan Imunisasi DPT pada anaknya sebanyak 52 orang $(71,3 \%)$ dan hanya sebagian kecil saja yang tidak melakukan imunisasi DPT yaitu sebanyak 10 orang $(13,7 \%)$ sedangkan Ibu yang memiliki sikap negatif sebagian kecil melakukan imunisasi DPT pada anaknya sebanyak 2 orang $(2,7 \%)$ dan sebagian kecil lainya tidak melaksanakan imunisasi DPT yaitu sebanyak 9 orang $(12,3 \%)$ 
Dari hasil penghitungan data, diperolah bahwa $\rho$ value adalah sebesar 0,00 sedangkan nilai $\alpha$ adalah 0,05 menurut Arikunto (2010) jika $\rho$ value kurang dari 0,05 menunjukan adanya hubungan yang bermakna antar variabel dalam penelitian tersebut, sehingga dapat disimpulkan bahwa ada hubungan antara sikap Ibu yang mempunyai bayi dengan pelaksanaan Imunisasi DPT di Puskesmas Kawali Kabupaten Ciamistahun 2018.

\section{PEMBAHASAN}

Hasil penelitian menunjukan bahwa sebanyak 11 orang $(15,1 \%)$ memiliki sikap negatif. Faktor sikap kurang baik ditunjukkan dengan tidak mau mengimunisasi anaknya kembali karena setelah imunisasi badannya panas. Jadi sesudah DPT 1 tidak mau kembali untuk diimunisasi DPT 2 dan DPT 3. Sikap responden berpengaruh signifikan terhadap perilaku kesediaan responden untuk mengimunisasi DPT anaknya. Hal ini diperkuat oleh teori yang dikemukakan Dimasqi (2004) menyebutkan sikap ibu balita terhadap imunisasi DPT berhubungan signifikan dengan kelengkapan imunisasi DPT.

Namun demikian terdapat sebanyak 2 orang responden yang memiliki sikap negatif (2.7\%) namun melakukan imunisasi, hal ini dapat disebabkan oleh adanya faktor luar seperti adanya dorongan dari kader atau pemerintah setempat yang tidak bisa ditolak, selain itu juga bisa disebabkan oleh dorongan sari tetangga atau orang dilingkunagn sekitar yang membuat yang bersangkutan merasa perlu untuk melakukan imunisasi.

Hasil ini sesuai dengan teori menurut Sarimin (2014), bahwa sikap orang tua memiliki hubungan dengan kelengkapan imunisasi dasar. Perbedaan sikap yang dimiliki ibu mempunyai hubungan signifikan dengan perilaku ibu dalam pemberian imunisasi dasar pada balita. Ibu dengan sikap negatif mempunyai peluang lebih besar untuk memiliki perilaku negatif dalam pemberian imunisasi dasar pada balita dan sikap positif mempunyai peluang lebih besar untuk memiliki perilaku positif dalam pemberian imunisasi dasar pada balita, namun demikian peluang tersebut tidak menjadi patokan bahwa pemilik sikap negative tidak akan melakukan kegiatan yang postif dikarenakan ada dorongan lain selain daripada siakp itu sendiri.

Sebanyak 62 orang $(84,9 \%)$ mempunyai sikap yang positif terhadap imunisasi, sikap positif ini adalah bentuk dari kepercayaan terhadap pelayanan kesehatan yaitu khususnya imunisasi. Kepercayaan ini sering diperoleh dari orang tua, kakek atau nenek dan orang terdekat lain ataupun dari penyuluhan penyuluhan dari petugas kesehatan

$$
\text { Menurut Azwar }
$$

kepercayaan muncul dari sesuatu yang telah dilihat dan telah diketahui. Berdasarkan apa yang telah dilihat dan 
diketahui terbentuk suatu ide atau gagasan mengenai sifat dan karakteristik umum objek. Kepercayaan juga dapat terbentuk dari kurang atau tidak mendapat informasi mengenai objek yang dihadapi.Tokoh panutan akan memengaruhi sikap seseorang terhadap suatu objek. Di antara orang yang biasanya dianggap penting bagi individu adalah orangtua, teman sebaya, guru, dan lain-lain. Individu cenderung untuk memiliki sikap yang dianggap sejalan dengan sikap orang yang dianggapnya penting. Selain itu, untuk membentuk suatu perilaku diperlukan suatu respon sikap yang sesuai agar pengetahuan dan perilaku berhubungan.Faktor-faktor lain yang turut memengaruhi sikap seseorang antara lain seperti fasilitas sumber informasi (misal: media massa, penyuluhan) dan faktor internal dari diri orang tersebut untuk menerima atau tidak menerima objek (sikap positif dan negatif).

Pada penelitian ini ditemukan sebsar 52 orang responden memiliki sikap yang positif terhadap imunisasi DPT dan melakukan imunisasi DPT hal ini disebabkan oleh sikap yang poitif terhadap suatu hal akan menyebabkan seseorang tersebut tertarik untuk melakukan hal tersebut. Hal ini sejalan dengan teori yang disampaiakan oleh Notoadmodjo (2010). menyatakan bahwa sikap merupakan reaksi atau respon yang masih tertutup dari seseorang terhadap suatu stimulus atau objek. Sikap juga merupakan kesiapan atau kesediaan untuk bertindak dan juga merupakan pelaksanaan motif tertentu Hasil penelitian ini sejalan dengan hasil penelitian Isnaini, Vivi dan Shobirun (2011) serta hasil penelitian Fitiyanti Ismet (2013) bahwa ada hubungan yang signifikan antara sikap ibu terhadap pemberian imunisasi dasar pada bayi.

Penelitian ini juga mengungkap bahwa sebgaian kecil dari ibu yang memiliki sikap positif yaitu sebanyak 10 orang $(13,7 \%)$ ternyata tidak melakukan imunisasi DPT lengkap terhadap anaknya hal ini bisa jadi dipengaruhi oleh beberapa faktor antara lain bahwa Kepercayaan responden tentang imunisasi DPT tidak berpengaruh terhadap perilaku kesediaan untuk mengimunisasi anaknya. bahwa masih adanya masyarakat yang percaya imunisasi DPT bisa panas sehingga cenderung memilih jenis imunisasi yang tidak mempunyai efek. Adanya kecenderungan imunisasi dikaitkan dengan keagamaan, selain daripada itu faktor akses kemudahan terhadap layanan kesehatan juga berpengaruh pada ibu untuk melakukan imunisasi pada anaknya, Akses kemudahan menjangkau tempat pelayanan kesehatan menjadi salah satu faktor yang mendukung masyarakat untuk berkunjung.

Hal ini sejalan dengan penelitian Nur Khotimah (2012), yang meneliti tentang faktor-faktor yang mempengaruhi kelengkapan imunisasi pada bayi, dari penelitian tersebut didapatkan hasil bahawa selain pengetahuan, sikap serta motivasi Ibudiketahui juga bahwa jarak ke pelayanan kesehatan berhubungan dengan kelengkapan imunisasi pada bayi, ha ini 
ditunjukan dengan proporsi ibu yang membawa anaknya untuk diimunisasi lebih banyak ibu yang bertempat tinggal dekat dengan fasilitas kesehatan $(69,7 \%)$ daripada ibu yang jarak tempat tinggalnya jauh.

Menurut Penelitian Gustdkk
(2004), antara pengetahuan dan sikap saling tarik menarik dimana pengetahuan merupakan fungsi dari sikap yang mendorong seseorang ingin tahu. Sikap ibu berhubungan dengan status imunisasi bayi. Sikap ibu yang positif terhadap imunisasi menyebabkan ibu membawa bayinya ke pusat pelayanan untuk mendapatkan kelengkapan imunisasi. Health belief model (HBM) mengenai imunisasi yang menyatakan bahwa sikap seseorang dalam mengikuti program imunisasi percaya bahwa: 1) kemungkinan terkena penyakit tinggi (ketidakkebalan), 2) jika terjangkit penyakit tersebut membawa akibat serius, 3) imunisasi adalah cara yang paling efektif untuk pencegahan penyakit dan 4) tidak ada hambatan serius untuk imunisasi.

Dari urian diatas sikap ibu besar kaitannya dengan pengetahuan ibu yang rendah. Pengetahuan yang rendah tentang imunisasi tidak lepas dari faktor pendidikan yang rendah dan informasi mengenai imunisasi. Kurangnya informasi tentang imunisasi yang didapatkan oleh ibu berakibat pada kepercayaan akan imunisasi yang rendah pula, sehingga aspek positif tentang berkurang, berpengaruh pula pada sikap ibu terhadap pemberian imunisasi pada anaknya. Orang tua merupakan orang yang biasa menjadi orang kepercayaan dalam keluarga. Sudah seharusnya memberikan pengaruh positif terhadap anaknya. Selain pengalaman dan juga informasi kemungkinan besar sudah banyak didapatkan, terutama mengenai imunisasi. Namun kenyataan dalam hasil penelitan ini justru peran orang tua sangat sedikit sekali berperan dalam memberikan imunisasi mengenai imunisasi kepada responden. Hal tersebut ikut mengakibatkan sikap responden terhadap imunisasi dasar lengkap pada anaknya.

Menurut Green dalam buku Notoatmodjo (2010) bahwa perilaku seseorang atau masyarakat tentang kesehatan ditentukan oleh pengetahuan, sikap dan karakteristik (pendidikan, kepercayaan, tradisi dan sebagainya) dari orang atau masyarakat yang bersangkutan. Disamping itu, ketersediaan fasilitas, sikap dan perilaku para petugas kesehatan terhadap kesehatan juga mendukung dan memperkuat terbentuknya perilaku.

Menurut Azwar (2013) Sikap merupakan suatu bentuk evaluasi atau reaksi perasaan. Sikap seseorang terhadap suatu objek adalah perasaan mendukung maupun perasaan tidak mendukung pada objek tersebut. Sikap ibu yang positif dapat menjadi faktor predisposing atau pencetus yang menyebabkan ibu membawa bayinya untuk di imunisasi. Sikap berhubungan terhadap suatu perilaku karena dipengaruhi oleh keyakinan bahwa perilaku akan membawa 
kepada hasil baik yang diinginkan maupun tidak diinginkan.

Manusia pada dasarnya selalu logis dan terasumsi sehingga berusaha menjaga konsistensi pengetahuan yang telah dimilikinya, namun ternyata harus berhadapan dengan kenyataan bahwa perilaku manusia seringkali irasional. Disonansi kognitif terjadi ketika seseorang memegang dua perilaku yang berbeda atau ketika kepercayaan tidak sejalan dengan perilaku. Sebagai contoh, seseorang yang memiliki pengetahuan baik belum tentu akan bersikap baik walaupun pengetahuan dan sikap dianggap dua hal yang berhubungan (Azwar, 2013).

Hasil penelitian menunjukkan bahwa anak yang sudah dilakukan imunisasi DPT sebagian besar mempunyai ibu dengan sikap positifsebanyak 52 responden,. Hasil uji Chi square menunjukkan bahwa nilai $\mathrm{p}=0,00<0,05$, maka Ha diterima dan dapat disimpulkan bahwa ada hubungan antara sikap Ibu dengan pelaksanaan imunisasi DPT di Puskesmas Kawali .

Hasil penelitian ini sejalan dengan penelitian yang dilakukan oleh Rizani dkk (2009) Hubungan Pengetahuan, Sikap dan Perilaku Ibu dalam Pemberian Imunisasi Hepatitis B 0 -7 Hari di Kota Banjarmasin, yang mendapatkan hasil bahwa sikap Ibu dalam pemberian Imunisasi mempunyai hubungan yang erat dengan pemberian Imunisasi ditunjukan dengan nilai $\mathrm{P}$ value 0,00

Penelitian lain yang sejaln dengan penelitian ini adalah penelitian yang dilakukan oleh Kumar (2010) di India dengan judul penelitian Immunization Status of Children Admitted to a Tertiarycare Hospital of North India: Reasons for Partial Immunization or Nonimmunization yang mendapatkan hasil bahwa sikap Ibu berhubungan erat dengan pelaksanaan pemberian Imunisasi pada anak.

Sikap adalah keteraturan tertentu dalam hal perasaan, pemikiran, predisposisi tindakan seseorang terhadap suatu aspek dilingkungan sekitarnya. Notoatmodjo (2010) berpendapat bahwa sikap merupakan kesiapan atau kesediaan untuk bertindak dan bukan merupakan pelaksaan motif tertentu. Sikap belum merupakan suatu tindakan atau aktifitas, tetapi merupakan predisposisi tindakan suatu perilaku. Faktor-faktor yang memegang peranan penting dalam penentuan sikap yang utuh adalah pengetahuan, pikiran, keyakinan dan emosi

Menurut Notoatmodjo (2010) bahwa pengetahuan seseorang tentang suatu objek mengandung dua aspek yaitu aspek positif dan aspek negatif. Kedua aspek ini akan menentukan sikap seseorang. Semakin banyak aspek positif dari objek diketahui, maka akan menimbulkan sikap semakin positif terhadap objek tetentu, salah satu bentuk objek kesehatan dapat dijabarkan oleh pengetahuan yang diperoleh dari pengalaman sendiri. Nilai afektif berkaitan dengan masalah subjektif seseorang terhadap suatu objek sikap. Secara umum, 
hal ini disamakan dengan perasaan yang dimiliki terhadap sesuatu. Reaksi afektif dipengaruhi oleh kepercayaan atau apa yang dipercayai seseorang sebagai hal yang positif atau negatif.

\section{KESIMPULAN}

Dari hasil analisa dan pembahasan maka peniliti dapat menyimpulkan hasil penelitian ini adalah hampir seluruhnya dari jumlah responden yang diteliti memiliki sikap positif terhadap pelaksanaan imunisasi DPT yaitu sebanyak 62 orang $(84,9 \%)$, dan didapatkan hampir seluruhnya dari jumlah responden yang diteliti melakukan Imunisasi DPT yaitu sebanyak 54 orang (74\%). Sehingga didapatkan hasil adanya hubungan antara sikap Ibu dengan pelaksanaan Imunisasi DPT di Puskesmas Kawali tahun 2018 dengan $\rho$ value adalah sebesar 0,00 .

Peneliti menyarankan kepada tenaga kesehatan khususnya pemegang program imunisasi agar meningkatkan penyuluhan ruin kepada masyarakat terutama ibu yang memiliki bayi baik secara individu ataupun kelompok. Penyuluhan secara individu dapat dilaksanakan pada waku kegiatan imunisasi, sedangkan penyuluhan kelompok dapat dilaksanakan pada waktuwaktu tertenu sesuai dengan jadwal yang telah ditentukan. Selain itu tenaga kesehatan juga dapat melakukan pelatihan kader posyandu sehingga kader juga dapat melakukan penyuluhan kepada masyarakat.

\section{DAFTAR PUSTAKA}

1. Arikunto, S. (2010), Prosedur Penelitian : Suatu Pendekatan Praktik : Cetakan ketiga. Jakarta.

2. Achmad, Umar Fahmi. 2010. Imunisasi Mengapa Perlu? Jakarta : Buku Kompas.

3. Azwar S. 2008. Sikap Manusia Teori dan Pengukurannya. Jakarta : Pustaka Pelajar.

4. Azwar. S. 2013. Sikap ManusiaTeoridanPengukurannya. PustakaPelajar. Yogyakarta

5. Baratawidjaja G.K, 2009. Imunisasi Dasar. Jakarta : Fakultas Kedokteran Universitas Indonesia..

6. Depkes RI. 2013. Imunisasi Dasar Bagi Pelaksana Imunisasi.

7. Depkes RI. 2015. Data AKB dan AKABA di Indonesia.

8. Dinkes Ciamis. 2017. Data Kesehatan Profil Ciamis.

9. Gunawan, dkk. Kejadian Ikutan Pasca Imunisasi Antigen Vi Polisakarida Kapsuler. Ilmu Kesehatan Anak. Jakarta : salemba medika, 2010.

10. Gust DA, Strine TW, Maurice E, Smith $\mathrm{P}$, Yusuf $\mathrm{H}$, Wilkinson $\mathrm{M}$, Battaglia M, Wright R, Schwartz B. 2004. Under Immunization Among Children Effects of Vaccine Safety Concern of Immunization Status. Journal of Pediatrics. 114:16-22.

11. Gustian, Agus. 2011. Aspek Perkembangan Motorik Anak Usia Dini. Yogyakarta : Liberty.

12. Kemenkes RI. 2014. Imunisasi Dasar lengkap. 
13. Kemenkes RI. 2016. Data Dan Informasi Kesehatan Profil Kesehatan Indonesia

14. Kumar. Devendradkk. 2010. Immunization Status of Children Admitted to a Tertiary-care Hospital of North India: Reasons for Partial Immunization or Non-immunization. J Health PopulNutr. 28(3):300304..

15. Mahayu, puri. 2016. Buku Lengkap Perawatan Bayi dan Balita. Yogyakarta: Saufa.

16. Mansjoer, A, dkk. 2008. Kapita Selekta Kedokteran. Jakarta: Media Aesculapius.

17. Marmi, dkk. Asuhan Kebidanan Patologi. Yogyakarta : Pustaka Belajar. 2011.

18. Muda, K.A. Ahmad (2009). Kamus Lengkap Kedokteran. Surabaya. Gita Media Pres.

19. Murti, B, 2010. Desain dan Ukuran Sampel Untuk Penelitian Kuantitatif dan Kualitatif di Bidang Kesehatan. Yogyakarta University Press.

20. Mutohir, Toho Cholik. 2011. Perkembangan Motorik Pada Masa Anak-anak. Jakarta : PT. Rineka Cipta.

21. Natalina, Johana, 2008. Tumbuh Kembang Anak, Bandung : Pustaka Binaan.

22. Notoatmodjo S. 2010. Metodologi Penelitian Kesehatan. Rev.ed. jakarta : Rineka Cipta.

23. Notoatmodjo. S. 2010. Promosi Kesehatan dan Ilmu Perilaku, RinekaCipta. Jakarta.
24. Nursalam. 2008. Konsep dan Penerapan Metodologi Penelitian Ilmu Keperawatan. Jakarta : Salemba Medika.

25. Proverawati, A, dkk. 2010. Imunisasi dan vaksinasi. Yogyakarta : Nuha Medika.

26. Qauliyah, A. 2008. Imunisasi, Pengertian, Jenis dan Ruang Lingkup. Available online : http // www.astaqualiyah.com. 16 maret 2009.

27. Ranuh, dkk. Buku Imunisasi Indonesia. Jakarta. Satgas Imunisasi IDAI, 2008.

28. Ranuh I.G.N Hariyono Suyitno, Hadinegoro, Soedjatmiko. 2008. Buku Imunisasi Di Indonesia. Jakarta. Satgas Imunisasi IDAI.

29. Rizani. Ahmad dkk. 2009. Hubungan Pengetahuan, Sikap dan Perilaku Ibu dalam Pemberian Imunisasi Hepatitis

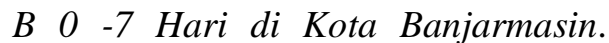
JurnalBeritaKedokteranMasyarakat. 25 (1):12-20.

30. Rusmila, Kusnandi, 2009. Pedoman Pelaksanaan Stimulasi, Deteksi, dan Intervensi Dini Tumbuh Kembang Anak. Jakarta : Depkes RI.

31. Sastro Asmoro, Sudigdo. 2007. Membina Tumbuh Kembang Bayi dan Balita. Jakarta. Ikatan Dokter Anak Indonesia.

32. Sugiyono (2007). Statistika Untuk Penelitian. Cetakan kedua belas. Bandung : Alfabeta.

33. Sulaeman. 2012. Hubungan sikap ibu yang mempunyai bayi dengan 
pelaksanaan imunisasi BCG di

Puskesmas Mangunjaya.

34. Tri Rusmi Widayatun (2007). Ilmu prilaku. M.A. 104. Jakarta.

35. Triania, Vivi. 2015.Faktor Yang Berhubungan Dengan Pemberian Imunisasi Dasar Lengkap Pada Bayi tahun 2015. Jurnal Kesehatan
Masyarakat Andalas. Vol 10 no 2 hal 123-135.

36. Wahidiyat, Iskandar. 2009. Ilmu Kesehatan Anak. 1. Jakarta : Infomedika.

37. Wawan A. dan Dewi M, (2010). Teori dan Pengukuran Pengetahuan, Sikap, dan Perilaku Manusia. Jogjakarta : Nuha Medika. 